\title{
PENGARUH IMPLEMENTASI GCG TERHADAP KINERJA BPJS KETENAGAKERJAAN PADA KANTOR CABANG DI WILAYAH DKI JAKARTA
}

Andy Faisal Aziz, Edi Prohantoro, I Made Yagustana

Program Pasca Sarjana Magister Manajemen Universitas Gunadarma

Jalan Kenari 13 Jakarta Pusat - 10430

e-mail: andy.faisal@bpjsketenagakerjaan.go.id

\begin{abstract}
This research was conducted to provide confidence in the effect of the implementation of GCG BPJS Ketenagakerjaan on the performance of branch offices in the DKI Jakarta area. Therefore a theoretical model with 15 hypotheses was proposed to be tested using the SEM method, through 255 respondents who were BPJS Ketenagakerjaan in the DKI Jakarta Region, as the largest contributor area of contributions compared to 10 other regions in Indonesia. Based on this research, it is known that the implementation of GCG in the form of Transparency is very significant, followed by the implementation of the Responsibility principle and the Fairness principle on the Expansion of Participation Performance, Service Satisfaction and Fee Acceptance, and in general there is a positive relationship on the implementation of GCG on Branch Office Performance. Based on this research it is recommended that the BPJS Employment Office be able to optimize the socialization, monitoring and evaluation on an ongoing basis on the implementation of GCG principles for managing the performance of Branch Offices in its area, so that the expected performance can be achieved and the quality and quantity can be continuously improved.
\end{abstract}

Keywords: Transparency, Responsibility, Fairness, Performance, Quality.

\begin{abstract}
Abstrak
Penelitian ini dilakukan untuk memberikan keyakinan pengaruh penerapan GCG BPJS Ketenagakerjaan terhadap kinerja kantor cabang di wilayah DKI Jakarta. Oleh karena itu diajukan model teoritis dengan 15 hipotesis untuk diuji dengan metode SEM, melalui 255 responden yang merupakan karyawan BPJS Ketenagakerjaan di Wilayah DKI Jakarta, sebagai wilayah terbesar penyumbang iuran dibandingkan 10 wilayah lainnya di Indonesia. Berdasarkan penelitian ini diketahui bahwa implementasi GCG berupa Transparansi sangat signifikan, diikuti implementasi prinsip Responsibilitas dan prinsip Fairness terhadap Kinerja Perluasan Kepesertaan, Kepuasan Pelayanan dan Penerimaan Iuran, dan secara umum terdapat hubungan positif atas penerapan GCG terhadap Kinerja Kantor Cabang. Berdasarkan penelitian tersebut disarankan agar Kantor BPJS Ketenagakerjaan dapat mengoptimalkan sosialisasi, monitoring serta evaluasi secara kontinue atas implementasi prinsip-prinsip GCG atas pengelolaan kinerja Kantor Cabang di wilayahnya, sehingga kinerja yang diharapkan dapat dicapai dan terus ditingkatkan kualitas dan kuantitasnya.
\end{abstract}

Kata Kunci : Transparansi, Responsibilitas, Kewajaran, Kinerja, Kualitas. 


\section{PENDAHULUAN}

Kinerja perusahaan telah menjadi topik yang menarik untuk dibahas, terutama yang terkait dengan eksplorasi faktor-faktor apa saja yang dapat meningkatkan dan mencegah kinerja organisasi. Kinerja organisasi mencerminkan kinerja dari pihak-pihak yang terkait dengan tata kelola, pembagian wewenang dan tanggung jawab yang berkaitan dengan hajat hidup sebuah perusahaan baik perusahaan jasa maupun manufaktur (Lusiana, 2018; Lamsah, 2018; Thoyibatun, 2009). Jasa asuransi, baik swasta, BUMN, maupun badan hukum yang dibentuk langsung oleh pemerintah, menjadi hal yang tidak terpisahkan dari kehidupan masyarakat di hari ini.

Salah satu badan hukum milik pemerintah Indonesia yang sedang tumbuh dan berkembang adalah Badan Pengelola Jaminan Sosial (BPJS). Visi BPJS Ketenagakerjaan adalah "Menjadi Badan Penyelenggara Jaminan Sosial Kebanggaan Bangsa, yang Amanah, Bertatakelola Baik serta Unggul dalam Operasional dan Pelayanan". Untuk mencapai hal tersebut dibutuhkan penerapan Good Governance secara terencana, sistemik, dan berkesinambungan yang didukung kelengkapan infrastruktur yang ada dan disertai komitmen seluruh insan BPJS
Ketenagakerjaan, Hal ini mutlak diperlukan sebagai modal dasar bagi keberlangsungan usaha lembaga serta mampu menjadi organisasi yang dipercaya oleh seluruh pemangku kepentingan khususnya para pekerja.

Salah satu manfaat utama BPJS Ketenagakerjaan bagi pekerja adalah mendapatkan perlindungan dan memberikan rasa aman kepada para pekerja, sehingga diharapkan para pekerja peserta BPJS Ketenagakerjaan dapat fokus dalam bekerja, lebih produktif dan memberikan output (hasil) yang berkualiatas dan efektif. Hal ini juga akan memberikan manfaat kepada pengusaha dan masyarakat terutama dalam ikut memberikan kontribusi dalam pertumbuhan perekonomian demi kesejahteraan masyarakat dan kemajuan bangsa serta negara.

Beberapa tahun belakangan ini BPJS Ketenagakerjaan secara nasional telah melakukan assesmen implementasi GCG/GG secara rutin setahun sekali, dalam 5 (lima) tahun terakhir skor atas penilaian assesmen tersebut mengalami peningkatan dan selalu mendapatkan predikat "Sangat Baik". Hal ini dapat dilihat pada rincian berikut ini:

\begin{tabular}{|c|l|l|}
\hline Tahun & Nilai & \multicolumn{1}{|c|}{ Predikat } \\
\hline 2017 & 95,69 & Sangat Baik \\
\hline 2016 & 95,54 & Sangat Baik \\
\hline 2015 & 95,49 & Sangat Baik \\
\hline 2014 & 95,26 & Sangat Baik \\
\hline 2013 & 95,04 & Sangat Baik \\
\hline
\end{tabular}

Sumber: Laporan Penilaian Penerapan Tata Kelola BPJS Ketenagakerjaan, 2013-2017

Hal ini menunjukan terdapat perbaikan penerapan GCG/GG dalam tata kelola di BPJS Ketenagakerjaan, terutama dalam hal kualitasnya. Kondisi tersebut juga didukung dengan penerapan tata kelola GCG di Kanwil dan Kantor Cabang, termasuk di
Kanwil dan Kantor Cabang di wilayah DKI Jakarta.

Meskipun pengujian dan penelitian empiris terhadap hubungan antara implementasi GCG/GG dan kinerja telah banyak dilakukan, dan berdasarkan 
penelitian-penelitian tersebut terdapat hubungan yang positif antara implementasi GCG/GG dengan Kinerja. Namun pengujian yang dilakukan masih bersifat umum sebagai institusi besar BPJS Ketenagakerjaan atau belum banyak yang fokus pada tata kelola GCG pada Kantor Cabang BPJS Ketenagakerjaan sebagai ujung tombak kinerja BPJS Ketenagakerjaan secara keseluruhan. Penelitian tersebut antara lain dilakukan oleh Yagustana (2016), Dengan judul "Pengaruh Immplementasi Good Governance terhadap Kinerja BPJS Ketenagakerjaan". Oleh karena itu Penulis ingin mengetahui tingkat hubungan antara 5 (lima) prinsip GCG yang terdiri atas Transparansi, Akuntabilitas, Responsibilitas, Independensi, dan Fairness (Kewajaran) dengan variabel kinerja yaitu Perluasan Kepesertaan, Kepuasan Peserta, dan Penerimaan Iuran, yang ada di Kantor Cabang.

Kantor Cabang yang dijadikan obyek penelitian adalah Kantor Cabang di wilayah DKI Jakarta. Hal ini dilakukan karena wilayah DKI Jakarta merupakan salah satu barometer utama perekonomian dan pusat bisnis di Indonesia, yang mana banyak perusahaan baik perusahaan negara maupun swasta banyak berpusat di Jakarta. Di samping itu Jakarta biasanya menjadi pusat sentralisasi dari pengelolaan upah dari seluruh karyawan perusahaan yang tersebar di Indonesia, sehingga dari segi kinerja dari BPJS Ketenagakerjaan sangat signifikan.

Berdasarkan uraian tersebut di atas, maka pada kesempatan ini peneliti akan melakukan penelitian dengan judul "Pengaruh Implementasi Good Corporate Governance Terhadap Kinerja BPJS Ketenagakerjaan pada Kantor Cabang di wilayah DKI Jakarta”. Dikarenakan BPJS Ketenagakerjaan merupakan badan hukum publik yang menyelenggarakan sistem jaminan sosial ketenagakerjaan berdasarkan prinsip nirlaba (UU No. 24 tahun 2011, pasal 4 dan 7), maka dalam penelitian ini variabel kinerja (performance) diukur berdasarkan Kinerja Perluasan Kepesertaan, Kinerja Kepuasan Pelayanan, dan Kinerja Penerimaan Iuran (Rencana Strategis BPJS Ketenagakerjaan, sedangkan variabel Good Governance sesuai dengan prinsip dasar GCG, yaitu Transparency, Accountability, Responsibility, Independency dan Fairness.

\section{TINJAUAN PUSTAKA}

Istilah "Corporate Governance" pertama kali diperkenalkan oleh Cadbury Committee di tahun 1992 dalam laporan mereka yang kemudian dikenal sebagai Cadbury Report dan merupakan titik balik (turning point) yang sangat menentukan bagi praktik Corporate Governance di seluruh dunia. Cadbury Committee (1992) mengemukakan bahwa Corporate Governance diartikan sebagai sistem yang berfungsi untuk mengarahkan dan mengendalikan perusahaan.

Kemudian pada tahun 1993 Good Corporate Governance menggolongkan korporasi (perseroan) modern sebagai institusi yang memisahkan kepemilikan (ownership) dari kontrol, akan tetapi pada waktu itu ungkapan Good Corporate Governance tidak digunakan relatif hingga belakangan ini. Pemisahan ini memberikan kewenangan kepada pengelola (manajer/direksi) untuk mengurus jalannya perusahaan, seperti mengelola dana dan mengambil keputusan perusahaan atas nama pemilik. Sampai beberapa tahun terakhir ini, Good Corporate Governance mengalami perkembangan waktu ke waktu, perkembangan ini muncul sebagai reaksi terhadap berbagai kegagalan korporasi sebagai akibat dari buruknya tata kelola perusahaan (Latifa \& Marvyn, 2005).

Corporate Governance dapat diartikan secara harafiah menjadi "tata kelola 
perusahaan”. Menurut Sutedi (2011), Corporate Governance dapat didefinisikan sebagai suatu proses dan struktur yang digunakan oleh organ perusahaan (Pemegang Saham / Pemilik Modal, Komisaris / Dewan Pengawas, dan Direksi) untuk meningkatkan keberhasilan usaha dan akuntabilitias perusahaan guna mewujudkan nilai atau kekayaan bagi para pemegang saham dalam jangka panjang dengan tetap memperhatikan kepentingan stakeholder lainnya, berlandaskan peraturan perundang-undangan dan nilai-nilai etika. Lebih lanjut Sutedi (2011) mengatakan bahwa Good Corporate Governance secara definitif merupakan sistem yang mengatur dan mengendalikan perusahaan untuk menciptakan nilai tambah untuk semua stakeholder.

Ada dua hal yang ditekankan dalam konsep ini, pertama adalah pentingnya hak pemegang saham untuk memperoleh informasi dengan benar dan akurat secara tepat waktu, dan kedua adalah kewajiban perusahaan untuk melakukan pengungkapan (disclosure) secara akurat, tepat waktu, dan transparan terhadap semua informasi kinerja perusahaan, kepemilikan, dan stakeholder. Secara singkat ada lima komponen utama yang diperlukan dalam GCG ini, yaitu transparency, accountability, responsibility, independency, dan fairness, .

Prinsip-prinsip Good Governance meliputi Transparency, terjaminnya keterbukaan dalam pengambilan keputusan dan keterbukaan dalam pengungkapkan informasi mengenai penyelenggaraan program jaminan sosial oleh BPJS Ketenagakerjaan sesuai peraturan perundang-undangan yang berlaku. Accountability, terselenggaranya kegiatan usaha BPJS Ketenagakerjaan yang menjelaskan fungsi, pelaksanaan dan pertanggungjawaban dari setiap pihak yang terkait dengan Organ BPJS Ketenagakerjaan sesuai peraturan perundang-undangan yang berlaku dan praktik yang berlaku umum.
Responsibility, terselenggaranya program jaminan sosial oleh BPJS Ketenagakerjaan yang dapat menjelaskan peranan dan status dari setiap pihak yang terkait untuk setiap proses pembuatan dan penerapan kebijakan.

Independency, pengelolaan BPJS Ketenagakerjaan secara professional yang bebas dari benturan kepentingan atau tekanan dan atau pengaruh dari setiap pihak manapun yang tidak sesuai dengan peraturan perundang-undangan yang berlaku.

Fairness, keadilan dan kesetaraan dalam memenuhi hak-hak setiap pihak yang timbul berdasarkan perjanjian dan perundang-undangan yang berlaku.

Kinerja merupakan hasil yang dicapai dari perilaku anggota organisasi (Gibson, 1993). Jadi kinerja organisasi merupakan hasil yang diinginkan organisasi dari perilaku orang-orang di dalamnya. Kaplan dan Norton (2006) mengembangakan tolak ukur keberhasilan perusahaan yang lebih komprehensif (kinerja), dengan nama Balanced Scorecard.

Berdasarkan sasaran strategis BPJS Ketenagakerjaan, disusunlah penetapan Key Performance Indicator (KPI) seluruh Kantor Cabang BPJS Ketenagakerjaan yang mendukung Kinerja BPJS Ketenagakerjaan secara Nasional. Kinerja utama Kantor Cabang BPJS Ketenagakerjaan berdasarkan Strategy Map Rencana Strategis BPJS Ketenagakerjaan setiap tahun sampai dengan tahun 2018 meliputi, Memperluas cakupan kepesertaan, sebagai Kinerja Perluasan Kepesertaan; Memberi pelayanan yang mudah, ramah, modern, dan bermanfaat lebih, sebagai Kinerja Kepuasan Pelayanan; Menjaga sustainability DJS dan BPJS Ketenagakerjaan, meningkatkan Dana Kelola yang efektif dan efisien, sebagai Kinerja Penerimaan Iuran. 


\section{METODE PENELITIAN}

\section{Jenis Penelitian}

Penelitin ini merupakan penelitian eksplanatori dengan menggunakan pendekatan kuantitatif. Model penelitian yang digunakan dalam penelitian ini adalah analisis regresi berganda, yakni model regresi atau prediksi yang melibatkan lebih dari satu variabel bebas atau prediktor atau

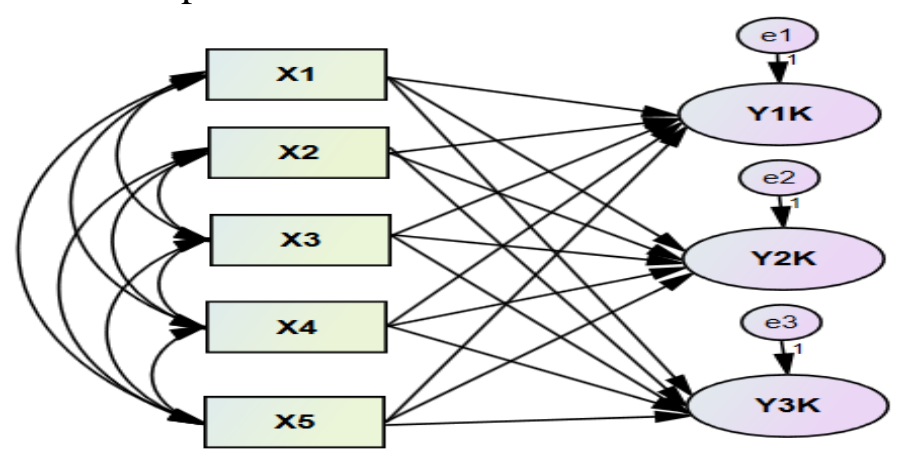

\section{Gambar 1. Desain Model untuk Diolah AMOS-SPSS}

Sumber: Model diolah oleh Peneliti, 2019

Keterangan :

a. $\quad$ Prinsip-Prinsip GG, yaitu: $\mathbf{X} 1=$ Transparansi, $\mathbf{X} \mathbf{2}=$ Akuntabilitas, $\mathbf{X} 3=$ Responsibilitas, $\mathbf{X} 4=$ Independensi, dan X5 = Kewajaran

b. $\quad$ Variabel Kinerja di Kantor Cabang, yaitu:: Y1K = Kinerja Kepesertaan, Y2K = Kinerja Pelayanan, dan Y3K $=$ Kinerja Keuangan; dan

c. $\quad \varepsilon=$ Variabel-Variabel diluar GG yang tidak diteliti.

d.

\section{Populasi dan Sampel}

Populasi penelitian ini adalah pegawai struktural dan fungsional Kantor Cabang di wilayah DKI Jakarta. Sampel yang diambil menggunakan teknik Non-Random Sampling, dengan Judgement Sampling Cooper dan Emory, 1995). Kriteria sampel responden merupakan pegawai BPJS Ketenagakerjaan yang aktif bekerja di BPJS Ketenagakerjaan baik struktural maupun fungsional dan memilki alamat email resmi BPJS Ketenagakerjaan. 270 kuesioner dikirimkan melalui aplikasi google drive dan didistribusikan langsung ke seluruh Kantor Cabang (17 Kacab) BPJS Ketenagakerjaan yang berada di wilayah DKI Jakarta. Dari 270 kuesioner yang dikirimkan hanya 255 jawaban kuesioner yang diisi dengan lengkap.
Apabila sampel yang didapat berjumlah 100 150 data untuk model struktural/SEM (Struktural Equation Modeling) dengan jumlah variabel laten (konstruk) sampai dengan lima buah, dan setiap konstruk dijelaskan oleh tiga atau lebih indikator menurut Singgih Santoso (2011) dalam Siswoyo (2012) sudah dianggap memadai. Berdasarkan perhitungan dengan metode Slovin didapatkan jumlah sampel yang wajar dan memadai dari populasi sebanyak 701 karyawan Kacab se-wilayah DKI Jakarta tahun 2018, dengan Taraf Kesalahan 5\% adalah sebanyak 255 responden karyawan, dengan perhitungan sebagai berikut:

$n=\frac{N}{1+N e^{2}}$ 


$$
\begin{aligned}
& n=\frac{701}{1+701(0.003)} \\
& n=\frac{701}{2.753} \\
& n=255
\end{aligned}
$$

Keterangan:

e $\quad$ : taraf kesalahan atau nilai kritis

$\mathrm{N} \quad$ : Populasi

$\mathrm{n} \quad$ : sampel minimal

\section{Metode Pengumpulan data}

Penelitian ini dilakukan melalui pendekatan survei dengan menggunakan kuesioner sebagai alat untuk mengumpulkan data dari seluruh responden, yang merupakan pegawai struktural dan fungsional di seluruh Kantor Cabang di wilayah DKI Jakarta. Kuesioner yang digunakan terdiri atas sejumlah pertanyaan dan/atau pernyataan tertulis berupa komponen-komponen operasional variabel penelitian dan telah ditetapkan beberapa alternatif jawabannya berdasarkan skala Likert. Skala Likert menurut Sugiyono (2017) digunakan sebagai alat untuk mengukur sikap, pendapat dan persepsi seseorang atau sekelompok orang tentang fenomena sosial. Skala Likert memiliki gradasi dari sangat positif sampai dengan sangat negatif dengan lima skala.

\section{Metode Analisis Data}

Penelitian ini menggunakan model persamaan struktur (Structural Equation Modelling/SEM) dengan bantuan aplikasi program AMOS (Analysis of Moment Structure) dalam melakukan analisis data. Analisis SEM adalah kombinasi dari berbagai tehnik multivariat yang mencoba menganalisis hubungan secara simultan antara variabel independen dengan dependen (Siswoyo Haryono, et all. 2012).

\section{Metode SEM (Structural Equation} Modelling) menurut Raykov (2000) dalam Siswoyo Haryono, et all. (2012) lebih sahih dan valid serta dapat digunakan untuk memberikan data/informasi yang lengkap mengenai hubungan antara konstruk dan indikator, serta hubungan antar konstruk yang dihipotesiskan (teori) oleh peneliti secara berkelanjutan (simultan). Di samping itu, SEM secara eksplisit akan menghitung pengukuran error yang terjadi pada model yang digunakan.

Hal yang perlu ditentukan dalam melakukan observasi objek penelitian (sering disebut objek pengamatan) adalah menentukan karakter atas objek yang diobservasi (diamati) tersebut, hal ini disebut variabel. (Sitinjak dan Sugiarto (2006) dalam Siswoyo Haryono, et all. (2012).

Variabel kunci dan menjadi perhatian di dalam SEM adalah variable laten menurut Siswoyo Haryono, et all. (2012). Variabel laten (unobserved variables) dalam SEM disebut juga dengan konstruk. Variabel laten tersebut diamati secara tidak langsung dan tidak sempurna, dan didapat dari dampak atau efek dari variabel teramati. Variabel Laten atau Konstruk ini diukur dengan sejumlah indikator/variable manifes/variabel teramati (observed variables) dan memiliki sifat eksogen maupun endogen.

Variabel laten eksogen merupakan variabel independen yang mempengaruhi variabel dependen. Pada model SEM, variabel laten eksogen digambarkan berupa anak panah yang berasal dari variabel tersebut menuju variabel laten endogen. Dan sebaliknya, variabel laten endogen merupakan variabel dependen yang dipengaruhi oleh variabel independen, dan digambarkan dengan adanya anak panah yang menuju variabel tersebut.

Secara umum analisis SEM menurut Siswoyo Haryono, et all. (2012) dilakukan melalui 2 (dua) tahapan yaitu tahap model pengukuran (measurement model) dan tahap model struktural (structural model), dengan penjelasan sebagai berikut:

1. Tahap Model Pengukuran (Measurement Model), dalam SEM setiap konstruk laten 
biasanya berhubungan dengan multiple seasure. Hubungan antara konstruk laten dengan pengukurannya dilakukan lewat faktor analytic measurement model, yaitu setiap konstuk laten dibuat model sebagai common factor dari pengukurannya (measurement). "factor loading" atau "Muatan-muatan faktor" yang menghubungkan suatu konstruk dengan pengukurannya diberi simbul dengan karakter Greek "lamda" label $\lambda$. Tujuan dari model pengukuran adalah untuk memperoleh konstruk atau variabel laten yang fit, sehingga dapat digunakan untuk analisis berikutnya. Identifikasi atas hal ini dilakukan dengan cara melihat nilai degrees of freedom (df) dari model yang dibuat. Pengujian hipotesis hanya dapat dilakukan bilamana model SEM mempunyai angka degrees offreedom (df) positif.

2. Tahap Model Struktural (Structural Model), model struktural merupakan suatu hubungan antar konstruk laten dan hubungan ini dianggap linear, meskipun demikian pengembangan lebih lanjut memungkinkan memasukkan persamaan non-linear. Secara grafis garis dengan satu kepala anak panah menunjukkan hubungan regresi dan garis dengan dua kepala anak panah menunjukkan hubungan korelasi atau kovarian. Analisis model struktural ini dimaksudkan untuk terlebih dahulu mendapatkan model struktural yang paling fit atau layak, sebelum dilakukan suatu pengujian hipotesa. Pengujian struktur model dapat dilakukan dengan pengujian overall model fit yang bertujuan untuk mengevaluasi secara umum derajat kesesuaian atau Goodness Of Fit antara data dengan model (Siswoyo Haryono, et all. 2012). Sehingga suatu model dikatakan telah fit dengan data sampel secara keseluruhan, jika pengujian overall model fit menghasilkan probability level yang lebih besar dari tingkat signifikansi $(\alpha)$.

3. Pengujian Hipotesis, Program AMOS digunakan untuk pengujian hipotesis atas pengaruh penerapan Good Governance terhadap kinerja Kantor Cabang BPJS Ketenagakerjaan di Wilayah DKI Jakarta beserta variabel independennya yang menjadi proksi masing-masing. Acuan dalam pengambilan keputusan dari pengujian hipotesis tersebut dengan melihat probabilitasnya. yaitu dengan melihat korelasi antar variabel eksogen, dan melihat pengaruh variabel Transparency (Keterbukaan), Accountability (Akuntabilitas), Responsibility (Pertanggungjawaban), Independency (Kemandirian), dan Fairness (Kesetaraan dan Kewajaran) terhadap Pendaftaran Peserta, Kepuasan Pelayanan, dan Penerimaan Iuran di Kantor Cabang BPJS Ketenagakerjaan di wilayah DKI Jakarta.

Pengolahan dengan program AMOS menghasilkan data berupa tabel Regression Weights dengan data/informasi terdiri atas: Estimate (b), standard errors (SE), critical ratio $(C R)$. Informasi tersebut menunjukkan tingkat signifikansi pengaruh suatu variabel independen terhadap variabel dependen. Sedangkan untuk kesimpulannya diterima atau ditolaknya suatu hipotesis menggunakan informasi dari data Probability Level $(P)$.

\section{HASIL DAN PEMBAHASAN}

Hasil

Statistik deskriptif dilakukan untuk mengetahui karakteristik responden yang diobservasi yang terdiri dari 255 responden yang akan memberikan gambaran mengenai identitas responden yang diformulasikan dalam bentuk tabel supaya lebih mudah dipahami, serta mengenai jawaban responden. Pembahasan dalam penelitian ini dijelaskan melalui dua tahapan analisis. 
Yaitu analisis deskriptif dan analisis model structural.

Penyajian data deskriptif dalam penelitian ini bertujuan agar dapat dilihat profil data penelitian tersebut dan hubungan yang ada antar variabel yang digunakan dalam penelitian tersebut. karakteristik responden yang diteliti berdasarkan jenis kelamin, masa kerja, dan jabatan digambarkan dalam Tabel 1, sebagai berikut:

Tabel 1. Analisis Deskriptif Responden

\begin{tabular}{|l|l|c|c|}
\hline \multirow{2}{*}{ Uraian } & Kriteria & $\begin{array}{l}\text { Frekuensi } \\
\text { Responden }\end{array}$ & $(\mathbf{\%})$ \\
\hline \multirow{2}{*}{$\begin{array}{l}\text { Jenis } \\
\text { Kelamin }\end{array}$} & Laki-Laki & 127 & 49.80 \\
& Perempuan & 128 & 50,20 \\
\cline { 2 - 4 } & Jumlah & $\mathbf{2 5 5}$ & $\mathbf{1 0 0}$ \\
\hline \multirow{5}{*}{ Masa Kerja } & $<5$ tahun & 113 & 44.30 \\
& $5-15$ tahun & 62 & 24,30 \\
\cline { 2 - 4 } & $>15-25$ tahun & 39 & 15,30 \\
\cline { 2 - 4 } & $>25$ tahun & 41 & 16,10 \\
\cline { 2 - 4 } Jabatan & Jumlah & $\mathbf{2 5 5}$ & $\mathbf{1 0 0}$ \\
\hline & Peiabat Struktural & 40 & 15.70 \\
\cline { 2 - 4 } & Pejabat Fungsional & 215 & 84,30 \\
\cline { 2 - 4 } & Jumlah & $\mathbf{2 5 5}$ & $\mathbf{1 0 0}$ \\
\hline
\end{tabular}

Sumber: Data primer diolah IBM-SPSS Statistics Viewer, 2019

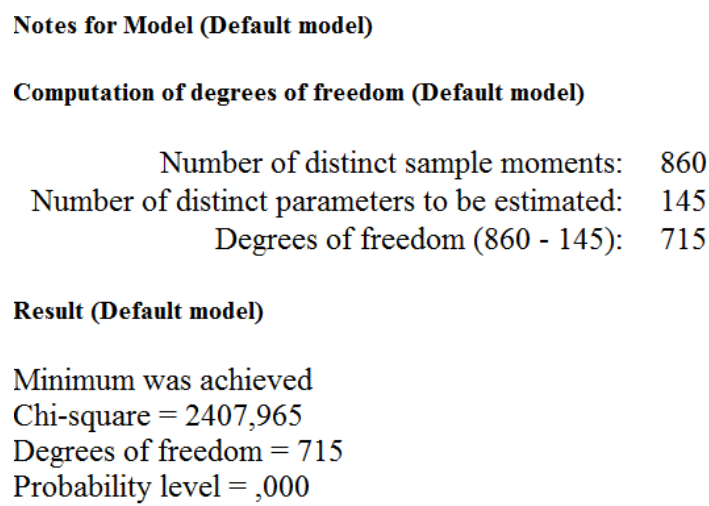

\section{Gambar 2. Perbandingan Data Responden}

Sumber: Data primer diolah, 2019

Pengujian model dengan menggunakan Structural Equation Modelling (SEM) dengan program Analysis of Moment Structure (AMOS) juga menghasilkan Degress of Freedom $(d f)$ yang positif juga, yaitu 715 atau di atas nol sehingga pengujian hipotesis dapat dilanjutkan, hal ini dapat dilihat pada gambar 2 .

Di samping itu tingkat probabilitas $=, 000$, jika asumsi distribusi yang tepat dipenuhi dan jika model yang ditentukan benar, maka nilai tersebut adalah perkiraan probabilitas untuk mendapatkan statistik chi-square sebesar statistik chi-square yang diperoleh dari set data saat ini, sehingga keberangkatan data dari model signifikan pada tingkat 0,05. Dalam tabel di atas terlihat bahwa model memiliki goodness of fit yang baik, karena nilai probability level dari Chi-Square lebih besar dari 0,05 yaitu sebesar 2407,965. Berdasarkan output yang dihasilkan tersebut menunjukkan bahwa secara keseluruhan 
(overall) model pertama telah fit dengan data sampel. Dalam pengujian struktur model akan ditunjukkan hubungan antara konstruk yang mempunyai hubungan kausal, (Siswoyo Haryono, et all. 2012). Struktur model akan ditunjukkan sebagai berikut:

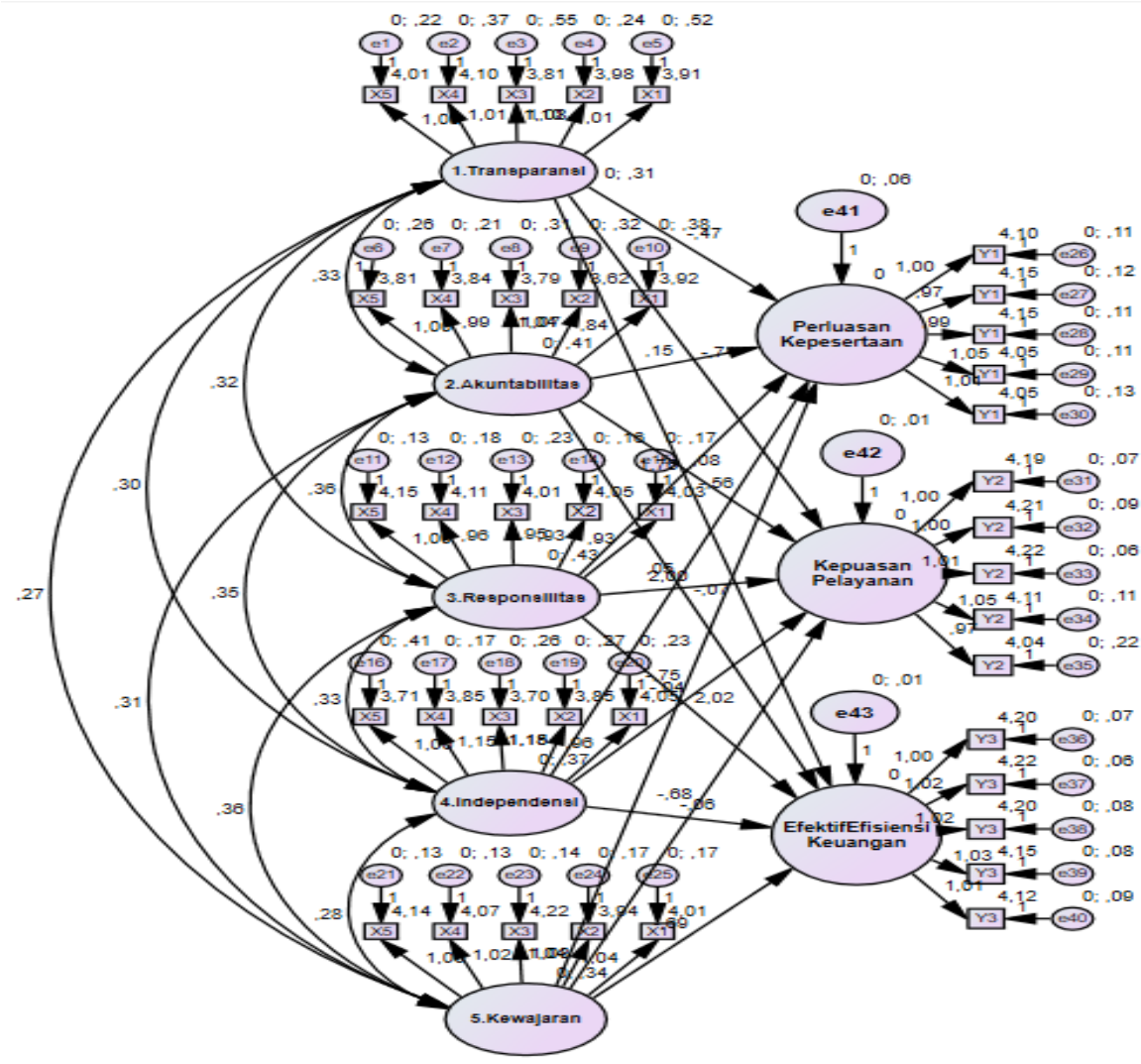

Gambar 3 Struktur Model Pengujian

Sumber: Diolah dari data primer, 2019

\section{Pengujian Hipotesis}

Pengujian pengaruh variabel eksogen (variabel independen) Good Governance (GG) dengan proksi Transparency (Keterbukaan), Accountability (Akuntabilitas), Responsibility (Pertanggungjawaban), Independency (Kemandirian), dan Fairness (Kesetaraan dan Kewajaran) terhadap variabel endogen (variabel dependen) Kinerja Kantor Cabang BPJS Ketenagakerjaan dengan proksi Perluasan Kepesertaan, Kepuasan Pelayanan, dan Penerimaan Iuran ditunjukkan dengan nilai estimate (b), standard error (SE), critical ratio $(\mathrm{CR})$, dan probability $(\mathrm{P})$ dalam tabel Regression Weight yang dihasilkan oleh AMOS.

Estimate (b), standard error (SE), critical ratio $(\mathrm{CR})$ menunjukkan tingkat signifikansi pengaruh suatu variabel independen terhadap variabel dependen. Sedangkan Probability level dapat digunakan untuk menarik simpulan diterima atau ditolaknya suatu hipotesis.

Nilai estimasi yang tinggi menunjukkan tingkat pengaruh yang besar. Karena koefisien estimasi bukan merupakan koefisien yang terstandarisasi, maka jangan melihat besar kecilnya nilai estimasi saja. Nilai estimasi tinggi tapi kalau standard error-nya tinggi sama saja, tidak signifikan pengaruhnya.

Nilai critical ratio $(\mathrm{CR})$ didapatkan dari nilai estimasi dibagi dengan standard error (SE). Semakin tinggi nilai CR maka semakin signifikan. Dengan ukuran sampel yang besar maka nilai $\mathrm{CR}$ di atas 1,96 akan menghasilkan nilai estimasi yang signifikan 
pada taraf 5\%, sedangkan jika di atas 2,56 akan signifikan pada taraf $1 \%$. Nilai estimasi yang terstandarisasi $(\beta)$ dapat digunakan untuk membandingkan besar tidaknya tingkat signifikansi pengaruh suatu variabel independen terhadap variabel dependen.

Nilai probabilitas (P) yang ditunjukkan dalam tabel Regression Weight dapat digunakan dalam pengambilan simpulan. Jika $\mathrm{P}>0,05$ maka Ho diterima, jika $\mathrm{P}<0,05$ maka Ho ditolak, (Siswoyo Haryono, et all. 2012)

Pengujian terhadap Hipotesis atas model yaitu hipotesis 1 sampai dengan hipotesis 15 akan didasarkan pada nilai Regression Weight berikut:

Tabel 2. Regression Weight

\begin{tabular}{|c|c|c|c|c|c|c|}
\hline & & & Estimate & S.E. & C.R. & $\mathbf{P}$ \\
\hline Perluasan_Kepesertaan & 4 & 2.Akuntabilitas & 0,146 & 0,216 & 0,673 & 0,501 \\
\hline Kepuasan_Pelayanan & 4 & 2.Akuntabilitas & 0,082 & 0,216 & 0,378 & 0,706 \\
\hline Kepuasan_Pelayanan & 4 & 3.Responsilitas & 2,002 & 0,198 & 10,1 & $* * *$ \\
\hline EfektifEfisiensi_Keu & 4 & 3.Responsilitas & 2,021 & 0,192 & 10,51 & *** \\
\hline EfektifEfisiensi_Keu & 4 & 4.Independensi & $-0,059$ & 0,163 & $-0,361$ & 0,718 \\
\hline Perluasan_Kepesertaan & 4 & 1.Transparansi & $-0,466$ & 0,241 & $-1,935$ & 0,053 \\
\hline Kepuasan_Pelayanan & 4 & 1.Transparansi & $-0,736$ & 0,248 & $-2,963$ & 0,003 \\
\hline EfektifEfisiensi_Keu & 4 & 5.Kewajaran & $-0,691$ & 0,181 & $-3,822$ & $* * *$ \\
\hline Perluasan_Kepesertaan & 4 & 3.Responsilitas & 1,762 & 0,196 & 8,981 & $* * *$ \\
\hline EfektifEfisiensi_Keu & 4 & 2.Akuntabilitas & $-0,065$ & 0,207 & $-0,314$ & 0,753 \\
\hline EfektifEfisiensi_Keu & 4 & 1.Transparansi & $-0,557$ & 0,232 & $-2,404$ & 0,016 \\
\hline Perluasan_Kepesertaan & 4 & 4.Independensi & 0,05 & 0,170 & 0,296 & 0,767 \\
\hline Kepuasan_Pelayanan & 4 & 4.Independensi & $-0,044$ & 0,169 & $-0,261$ & 0,794 \\
\hline Perluasan_Kepesertaan & 4 & 5.Kewajaran & $-0,747$ & 0,190 & $-3,942$ & $* * *$ \\
\hline Kepuasan_Pelayanan & 4 & 5.Kewajaran & $-0,677$ & 0,187 & $-3,624$ & $* * *$ \\
\hline
\end{tabular}

Sumber: Diolah dari data, 2019

Berdasarkan output yang dihasilkan, diketahui bahwa terdapat dua sifat pengaruh yang dihasilkan 5 (lima) variabel Independent (Transparancy/ Keterbukaan, Accountability/Akuntabilitas, Responsibility/ Pertanggungjawaban, Independency/ Kemandirian, dan Fairness/ Kewajaran). terhadap 3 variabel Dependent (Perluasan Kepesertaan, Kepuasan Pelayanan, dan Penerimaan Iuran (Efektifitas dan Efisiensi Keuangan). Untuk dasar menganalisis hasil output tersebut merujuk kepada Bab III Metode Penelitian yang telah dijelaskan sebelumnya. Rincian dan uraian dari hasil pengujian hipotesis 1 sampai dengan 15 pada table 3 adalah sebagai berikut:
Berdasarkan Tabel 3 hasil pengujian atas hipotesis pertama adalah ditolak ( $P$ senilai $\mathbf{0 , 0 5 3 ~ > ~ 0 , 0 5 0 ) ~ y a n g ~ b e r a r t i ~ v a r i a b e l ~}$ penerapan prinsip GG yaitu Transparency (Keterbukaan) tidak berpengaruh terhadap kinerja Perluasan Kepesertaan di kantor cabang BPJS Ketenagakerjaan di wilayah DKI Jakarta. Hal ini terjadi karena tetap harus ada batasan dalam menerapkan prinsip Transparency (Keterbukaan), terutama yang dapat berdampak pada keenganan para pekerja untuk mendaftarkan diri atau didaftarkan sebagai peserta BPJS Ketenagakerjaan. Batasan yang dimaksud antara lain: hasil audit yang sangat sensitif, isu-isu negatif internal BPJS Ketenagakerjaan, serta hal-hal yang secara 
politik mempengaruhi kebijakan yang diambil oleh manajemen BPJS Ketenagakerjaan (ASN gagal jadi peserta BPJS Ketenagakerjaan, tidak berjalannya UU tentang BPJS, dll) yang dapat merusak citra dan mengganggu operasional BPJS Ketanagkerjaan di mata publik.

Berdasarkan Tabel 3 hasil pengujian atas hipotesis kedua adalah diterima (P senilai $\mathbf{0 , 0 0 3}<\mathbf{0 , 0 5 0 )}$ yang berarti variabel penerapan prinsip GG yaitu Transparency (Keterbukaan) berpengaruh secara signifikan terhadap kinerja Kepuasan Pelayanan di kantor cabang BPJS Ketenagakerjaan di wilayah DKI Jakarta. Hal ini dilihat dari indikasi adanya kemudahan dalam memperoleh akses atas prosedur dan tata cara pelayanan dari personil kepada peserta, penekanan atas informasi tentang tidak adanya pungutan liar atau gratis dalam memberikan pelayanan kepada peserta, dan strategi atau kebijakan yang jelas disampaikan kepada Kantor Cabang.

Berdasarkan Tabel 3 hasil pengujian atas hipotesis ketiga adalah diterima yang berarti variabel penerapan prinsip GG yaitu Transparency (Keterbukaan) berpengaruh terhadap kinerja Penerimaan Iuran (Efektifitas dan Efisiensi Keuangan) di kantor cabang BPJS Ketenagakerjaan di wilayah DKI Jakarta, antara lain adanya informasi yang disajikan dan dikirimkan secara on line dan up to date kepada masingmasing peserta, termasuk iuran, hasil pengembangan, dan saldo akhir JHT peserta, serta program-program yang diikuti.

Berdasarkan Tabel 3 hasil pengujian atas hipotesis keempat adalah ditolak yang berarti variabel penerapan prinsip GG yaitu Accountability (Akuntabilitas) tidak berpengaruh terhadap kinerja Perluasan Kepesertaan di kantor cabang BPJS Ketenagakerjaan di wilayah DKI Jakarta. Hal ini memiliki kecenderungan merupakan kewajiban-kewajiban internal dari Manajemen Pusat dan Kantor
Wilayah/Cabang

dalam

membuat

pertanggungjawaban dari operasional yang dilakukan kepada Kantor Pusat. Hal ini tidak berpengaruh antara akuntabilitas dengan perluasan Kepesertaan.

Berdasarkan Tabel 3 hasil pengujian atas hipotesis kelima adalah ditolak yang berarti variabel penerapan prinsip GG yaitu Accountability (Akuntabilitas) tidak berpengaruh terhadap kinerja Kepuasan Pelayanan di kantor cabang BPJS Ketenagakerjaan di wilayah DKI Jakarta. Hal ini terkait dengan tidak adanya pengaruh atas pertanggungjawaban pelaksanaan kegiatan yang dianggarkan dalam RKAT setiap tahun, karena hal ini merupakan bentuk akuntabilitas dari BPJS Ketanagekerjaan kepada Manajemen, Dewan Pengawas dan Pemerintah (sebagai Pemilik/Owner).

Berdasarkan Tabel 3 hasil pengujian atas hipotesis keenam adalah ditolak yang berarti variabel penerapan prinsip GG yaitu Accountability (Akuntabilitas) tidak berpengaruh terhadap kinerja Penerimaan Iuran (Efektifitas dan Efisiensi Keuangan) di kantor cabang BPJS Ketenagakerjaan di wilayah DKI Jakarta. Hal ini lebih mengarah pada akuntabilitas realisasi atas RKAT untuk mendukung operasional Kacab BPJS Ketenagakerjaan tidak berpengaruh terhadap penerimaan iuran (efektif dan efisiensi keuangan).

Berdasarkan Tabel 3 hasil pengujian atas hipotesis ketujuh adalah diterima yang berarti variabel penerapan prinsip GG yaitu Responsibility (Pertanggungjawaban) berpengaruh secara signifikan terhadap kinerja Perluasan Kepesertaan di kantor cabang BPJS Ketenagakerjaan di wilayah DKI Jakarta. Hal ini dapat dilihat dari berjalannya dengan baik program Corporate Social Responsibility (CSR) terhadap publik, sehingga masyarakat lebih mengenal BPJS Ketenagakerjaan.

Berdasarkan Tabel 3 hasil pengujian atas hipotesis kedelapan adalah diterima yang 
berarti variabel penerapan prinsip GG yaitu Responsibility

(Pertanggungjawaban)

berpengaruh secara signifikan terhadap kinerja Kepuasan Pelayanan kantor cabang BPJS Ketenagakerjaan di wilayah DKI Jakarta. Kepuasan pelayanan merupakan kewajiban BPJS Ketenagakerjaan agar pegawai di Kantor Cabang dapat memberikan pelayanan yang terbaik. Salah satunya adalah diperhatikannya keluhankeluhan terutama keluhan peserta yang selalu ditindalanjuti dengan baik akan berpengaruh kepada kepuasan pelayanan peserta.

Berdasarkan Tabel 3 hasil pengujian atas hipotesis kesembilan adalah diterima yang berarti variabel penerapan prinsip GG yaitu Responsibility

(Pertanggungjawaban) berpengaruh secara signifikan terhadap kinerja Penerimaan Iuran kantor cabang BPJS Ketenagakerjaan di wilayah DKI Jakarta. Hal ini juga dapat dilihat salah satunya adalah dari berjalannya dengan baik program Corporate Social Responsibility (CSR) terhadap publik, yang memberikan kesadaran kepada para peserta BPJS Ketenagakerjaan bahwa dari pengelolaan dana atau iuran yang dilakukan BPJS Ketenagakerjaan yang berasa dari pembayaran iuran BPJS Ketenagakerjaan dari para peserta digunakan juga bagi kegiatan social yang membantu masyarakat umum. Hal ini memberikan kesadaran dan kepercayaan dari peserta untuk membayar iuran pada waktu dan jumlah yang tepat, sehingga berpengaruh terhadap peningkatan penerimaan iuran atau peningkatan pengelolaan keuangan yang efektif dan efisien.

Berdasarkan Tabel 3 hasil pengujian atas hipotesis kesepuluh adalah ditolak yang berarti variabel penerapan prinsip GG yaitu Independency (Kemandirian) tidak berpengaruh terhadap kinerja Perluasan Kepesertaan kantor cabang BPJS Ketenagakerjaan di wilayah DKI Jakarta. Hal ini cenderung lebih dilihat dari kemandirian dalam melaksanakan operasional Kantor Cabang, hal ini tidak menjadi perhatian masyarakat dalam rangka menjadi peserta BPJS Ketenagakerjaan.

Berdasarkan Tabel 3 hasil pengujian atas hipotesis kesebelas adalah ditolak yang berarti variabel penerapan prinsip GG yaitu Independency (Kemandirian) tidak berpengaruh terhadap kinerja Kepuasan Pelayanan kantor cabang BPJS Ketenagakerjaan di wilayah DKI Jakarta. Kemandirian dalam hal ini dalam melaksanakan operasional kantor cabang, hal ini tidak menjadi perhatian karyawan maupun masyarakat dalam menilai kinerja atas kepuasan pelayanan Kacab BPJS Ketenagakerjaan.

Berdasarkan Tabel 3 hasil pengujian atas hipotesis kedua belas adalah ditolak yang berarti variabel penerapan prinsip GG yaitu Independency (Kemandirian) tidak berpengaruh terhadap kinerja Penerimaan Iuran (Efektifitas dan Efisiensi Keuangan) kantor cabang BPJS Ketenagakerjaan di wilayah DKI Jakarta. Kemandirian dalam hal ini dalam melaksanakan operasional kantor cabang, hal ini dikarenakan adanya kepastian dalam pembayaran iuran, baik nilai maupun ketepatan waktunya yang tersistemasi secara otomatis, sehingga hal ini tidak mempengaruhi kinerja Penerimaan Iuran (Efektifitas dan Efisiensi Keuangan) Kacab BPJS Ketenagakerjaan.

Berdasarkan Tabel 3 hasil pengujian atas hipotesis ketiga belas adalah diterima yang berarti variabel penerapan prinsip GG yaitu Fairness (Kewajaran) berpengaruh secara signifikan terhadap kinerja Perluasan Kepesertaan kantor cabang BPJS Ketenagakerjaan di wilayah DKI Jakarta. Kewajaran dalam kebijakan (UU, Perpres, Perdir, SOP) untuk menarik peserta untuk menjadi peserta BPJS Ketenagakerjaan mempengaruhi kinerja Perluasan Kepesertaan Kacab BPJS Ketenagakerjaan. 
Berdasarkan Tabel 3 hasil pengujian atas hipotesis keempat belas adalah diterima yang berarti variabel penerapan prinsip GG yaitu Fairness (Kewajaran) berpengaruh secara signifikan terhadap kinerja Kepuasan Pelayanan kantor cabang BPJS Ketenagakerjaan di wilayah DKI Jakarta. Kewajaran dalam kebijakan (UU, Perpres, Perdir, SOP) untuk memberikan pelayanan kepada peserta BPJS Ketenagakerjaan mempengaruhi penilaian kinerja Kepuasan Pelayanan Kacab BPJS Ketenagakerjaan.

Berdasarkan Tabel 3 hasil pengujian atas hipotesis kelima belas adalah diterima yang berarti variabel penerapan prinsip GG yaitu Fairness (Kewajaran) berpengaruh secara signifikan terhadap kinerja Penerimaan Iuran (Efektifitas dan Efisiensi Keuangan) kantor cabang BPJS Ketenagakerjaan di wilayah
DKI Jakarta. Kewajaran dalam kebijakan (UU, Perpres, Perdir, SOP) penetapan iuran (mempertimbangkan Upah Minimum Provinsi/Upah Minimum Kota atau Kabupaten) dan kemudahan dalam melakukan pembayaran iuran, serta pemanfaatannya bagi kemudahan peserta dalam membayar iuran program BPJS Ketenagakerjaan mempengaruhi kinerja Penerimaan Iuran (Efektifitas dan Efisiensi Keuangan) Kacab BPJS Ketenagakerjaan.

Kemudian pada Tabel 6 di bawah ini terlihat bahwa seluruh estimasi bernilai positif dengan pengertian bahwa jika parameter masing-masing variabel meningkat 1 poin, maka nilai variabel variabel juga akan meningkat sesuai estimasi masing-masing yang terdapat pada Tabel tersebut.

Tabel 6. Standardized Regression Weight Parameter Setiap Variabel Independen

\begin{tabular}{|c|c|c|c|c|c|}
\hline \multicolumn{2}{|c|}{ Standardized Regression Weights: } & \multirow{2}{*}{$\begin{array}{l}\text { Estimate } \\
0,773\end{array}$} & \multicolumn{2}{|c|}{ Standardized Regression Weights: } & \multirow{2}{*}{$\begin{array}{l}\text { Estimate } \\
0,858\end{array}$} \\
\hline $\mathrm{X} 12$ & 1.Transparansi & & $\mathrm{X} 54$ & 5.Kewajaran & \\
\hline $\mathrm{X} 15$ & 1.Transparansi & 0,764 & $\mathrm{X} 55$ & 5.Kewajaran & 0,855 \\
\hline X14 & 1.Transparansi & 0,681 & X53 & 5.Kewajaran & 0,848 \\
\hline $\mathrm{X} 13$ & 1.Transparansi & 0,640 & X52 & 5.Kewajaran & 0,827 \\
\hline $\mathrm{X} 11$ & 1.Transparansi & 0,618 & X51 & 5.Kewajaran & 0,826 \\
\hline $\mathrm{X} 24$ & 2.Akuntabilitas & 0,813 & Y41 & Perluasan_Kepesertaan & 0,905 \\
\hline $\mathrm{X} 25$ & 2.Akuntabilitas & 0,785 & Y11 & Perluasan_Kepesertaan & 0,904 \\
\hline $\mathrm{X} 22$ & 2.Akuntabilitas & 0,770 & Y31 & Perluasan_Kepesertaan & 0,899 \\
\hline $\mathrm{X} 23$ & 2.Akuntabilitas & 0,767 & Y51 & Perluasan_Kepesertaan & 0,885 \\
\hline $\mathrm{X} 21$ & 2.Akuntabilitas & 0,655 & Y21 & Perluasan_Kepesertaan & 0,882 \\
\hline $\mathrm{X} 35$ & 3.Responsilitas & 0,875 & Y32 & Kepuasan_Pelayanan & 0,935 \\
\hline $\mathrm{X} 32$ & 3.Responsilitas & 0,837 & Y12 & Kepuasan_Pelayanan & 0,923 \\
\hline X34 & 3.Responsilitas & 0,828 & Y22 & Kepuasan_Pelayanan & 0,909 \\
\hline X31 & 3.Responsilitas & 0,827 & Y42 & Kepuasan_Pelayanan & 0,900 \\
\hline X33 & 3.Responsilitas & 0,793 & Y52 & Kepuasan_Pelayanan & 0,799 \\
\hline X44 & 4.Independensi & 0,860 & Y23 & EfektifEfisiensi_Keu & 0,933 \\
\hline $\mathrm{X} 43$ & 4.Independensi & 0,815 & Y13 & EfektifEfisiensi_Keu & 0,927 \\
\hline $\mathrm{X} 42$ & 4.Independensi & 0,802 & Y33 & EfektifEfisiensi_Keu & 0,920 \\
\hline X41 & 4.Independensi & 0,773 & Y43 & EfektifEfisiensi_Keu & 0,918 \\
\hline $\mathrm{X} 45$ & 4.Independensi & 0,685 & Y53 & EfektifEfisiensi_Keu & 0,908 \\
\hline
\end{tabular}

Sumber: Diolah dari data primer dengan IBM SPSS-AMOS 21.0.0, 2019

\section{Pembahasan}

Untuk lebih mengetahui pengaruh dari masing-masing variabel akan digunakan hasil pengujian pada Tabel 3 Regression
Weight sebagai dasar ukuran tingkat penaruhnya, sehingga dapat kami uraikan pengaruh dari masing masing variabel 
Independen GCG pada Kantor Cabang di wilayah DKI Jakarta, sebagai berikut.

Berdasarkan hasil pengujian dan analisa yang telah dilakukan tersebut di atas, diketahui bahwa variable GCG Transparency (Keterbukaan) berpengaruh signifikan terhadap variable kinerja Penerimaan Iuran (Efektifitas dan Efisiensi Keuangan) atau Hipotesis (H3) Diterima, sedangkan pengaruh terhadap kinerja Perluasan Kepesertaan dan kinerja Kepuasan Pelayanan tidak signifikan (Hipotesis Ditolak). Transparency (Keterbukaan) adalah terjaminnya keterbukaan dalam pengambilan keputusan dan keterbukaan dalam pengungkapkan informasi mengenai penyelenggaraan program jaminan sosial oleh Kantor Cabang BPJS Ketenagakerjaan di wilayah DKI Jakarta sesuai peraturan perundang-undangan yang berlaku. Hal ini menunjukan bahwa upaya Kantor Cabang BPJS Ketenagakerjaan di wilayah DKI Jakarta dalam menerapkan prinsip Transparency (Keterbukaan) untuk mendukung operasional dan kinerja Kantor Cabang belum seluruhnya berdampak langsung dan signifikan kepada Kinerja Kantor Cabang. Kemudian dari lima parameter dari variabel yang diukur pada Tabel 6. Regression Weight diketahui bahwa seluruhnya memiliki pengaruh terhadap transparansi (keterbukaan) yang dilihat dari Probabilitas (P) dengan nilai default 0,001 $(* * *)$ atau $<0,05$. Hal ini menunjukan bahwa upaya Manajemen Kantor Cabang BPJS Ketenagakerjaan di wilayah DKI Jakarta dalam menerapkan prinsip Transparansi untuk mendukung operasional dan kinerja Kantor Cabang sudah terlihat pengaruhnya yang signifikan kepada Kinerja Kantor Cabang melalui nilai kelima parameter tersebut di atas dan probabilitas $(\mathrm{P})$ kelima paremeternya $<0,05$.

Berdasarkan hasil pengujian dan analisa yang telah dilakukan tersebut di atas, diketahui bahwa variable GCG
Accountability (Akuntabilitas) berpengaruh signifikan terhadap variable kinerja Perluasan Kepesertaan atau Hipotesis atau H4 Diterima, sedangkan pengaruh terhadap kinerja Penerimaan Iuran (Efektifitas dan Efisiensi Keuangan) dan kinerja Kepuasan Pelayanan tidak signifikan atau Hipotesis Ditolak. Akuntabilitas (Accountability) adalah terselenggaranya kegiatan usaha BPJS Ketenagakerjaan yang menjelaskan fungsi, pelaksanaan dan pertanggungjawaban dari setiap pihak yang terkait dengan Organ BPJS Ketenagakerjaan sesuai peraturan perundang- undangan yang berlaku dan praktik yang berlaku umum. Hal ini juga menunjukan bahwa upaya Manajemen BPJS Ketenagakerjaan di wilayah DKI Jakarta dalam menerapkan prinsip Accountability (Akuntabilitas) untuk mendukung operasional dan kinerja Kantor Cabang belum seluruhnya berdampak langsung dan signifikan kepada Kinerja Kantor Cabang. Kemudian dari variabel yang diukur pada Tabel 6. Regression Weight terdapat lima parameter variabel akuntabilitas (pertanggungjawaban) yang diukur diketahui bahwa seluruhnya memiliki pengaruh terhadap variabel akuntabilitas yang dilihat dari Probabilitas (P) dengan nilai default $0,001(* * *)$ atau $<0,05$. Hal ini menunjukan bahwa upaya Manajemen Kantor Cabang BPJS Ketenagakerjaan di wilayah DKI Jakarta dalam menerapkan prinsip Akuntabilitas untuk mendukung operasional dan kinerja Kantor Cabang sudah terlihat pengaruhnya yang signifikan kepada Kinerja Kantor Cabang, melalui nilai kelima parameter tersebut di atas dan probabilitas $(\mathrm{P})$ kelima paremeternya $<0,05$.

Berdasarkan hasil pengujian dan analisa yang telah dilakukan tersebut di atas, diketahui bahwa variable GCG Responsibility (Pertanggungjawaban) berpengaruh signifikan terhadap seluruh atau ketiga hipotesis atau H1 Diterima, yaitu terdiri atas: H7: Penerapan Prinsip 
Responsibility (Pertanggungjawaban) berpengaruh signifikan terhadap Perluasan Kepesertaan; H8: Penerapan Prinsip Responsibility (Pertanggungjawaban) berpengaruh signifikan terhadap Kepuasan Pelayanan; H9: Penerapan Prinsip Responsibility (Pertanggungjawaban) berpengaruh signifikan terhadap Penerimaan Iuran. Responsibilitas (Responsibility) adalah terselenggaranya program jaminan sosial oleh Kantor Cabang BPJS Ketenagakerjaan yang dapat menjelaskan peranan dan status dari setiap pihak yang terkait dengan BPJS Ketenagakerjaan untuk setiap proses pembuatan dan penerapan kebijakan di BPJS Ketenagakerjaan terutama yang terkait dengan Kantor Cabang BPJS Ketenagakerjaan di wilayah DKI Jakarta. Hal tersebut di atas menunjukan bahwa upaya Manajemen BPJS Ketenagakerjaan di wilayah DKI Jakarta dalam menerapkan prinsip Responsibility (Pertanggungjawaban) untuk mendukung operasional dan kinerja Kantor Cabang sepenuhnya berdampak langsung dan signifikan kepada Kinerja Kantor Cabang. Kemudian dari variabel yang diukur pada Tabel 6. Regression Weight terdapat lima parameter variabel Responsibilitas (Responsibility) yang diukur diketahui bahwa seluruhnya memiliki pengaruh terhadap variabel Responsibilitas (Responsibility) yang dilihat dari Probabilitas $(\mathrm{P})$ dengan nilai default 0,001 $(* * *)$ atau $<0,05$. Hal ini menunjukan bahwa upaya Manajemen Kantor Cabang BPJS Ketenagakerjaan di wilayah DKI Jakarta dalam menerapkan prinsip Responsibilitas (Responsibility) untuk mendukung operasional dan kinerja Kantor Cabang sudah terlihat pengaruhnya yang signifikan kepada Kinerja Kantor Cabang, melalui nilai kelima parameter tersebut di atas dan probabilitas $(\mathrm{P})$ kelima paremeternya $<0,05$.

Berdasarkan hasil pengujian dan analisa yang telah dilakukan tersebut di atas, diketahui bahwa variable GCG
Independency (Kemandirian) berpengaruh signifikan terhadap variable kinerja Kepuasan Pelayanan atau Hipotesis atau H4 Diterima, sedangkan pengaruh terhadap kinerja Penerimaan Iuran (Efektifitas dan Efisiensi Keuangan) dan kinerja Perluasan Kepesertaan tidak signifikan atau Hipotesis Ditolak (Ho Ditolak). Independency (Kemandirian) adalah terselenggaranya kegiatan usaha di Kantor Cabang BPJS Ketenagakerjaan se-wilayah DKI Jakarta yang menjelaskan fungsi, pelaksanaan dan pertanggungjawaban dari setiap pihak yang terkait dengan Organ BPJS Ketenagakerjaan sesuai peraturan perundang- undangan yang berlaku dan praktik yang berlaku umum. Hal ini juga menunjukan bahwa upaya Manajemen BPJS Ketenagakerjaan di wilayah DKI Jakarta dalam menerapkan prinsip Independency (Kemandirian) untuk mendukung operasional dan kinerja Kantor Cabang belum seluruhnya berdampak langsung dan signifikan kepada Kinerja Kantor Cabang. Kemudian dari variabel yang diukur pada Tabel 6. Regression Weight terdapat lima parameter variabel Independency (Kemandirian) yang diukur diketahui bahwa seluruhnya memiliki pengaruh terhadap variabel Independency (Kemandirian) yang dilihat dari Probabilitas (P) dengan nilai default $0,001(* * *)$ atau $<0,05$. Hal ini menunjukan bahwa upaya Manajemen Kantor Cabang BPJS Ketenagakerjaan di wilayah DKI Jakarta dalam menerapkan prinsip Independency (Kemandirian) untuk mendukung operasional dan kinerja Kantor Cabang sudah terlihat pengaruhnya yang signifikan kepada Kinerja Kantor Cabang, melalui nilai kelima parameter tersebut di atas dan probabilitas $(\mathrm{P})$ kelima paremeternya $<0,05$.

Berdasarkan hasil pengujian dan analisa yang telah dilakukan tersebut di atas, diketahui bahwa variable GCG berpengaruh signifikan terhadap dua dari ketiga hipotesis atau H1 Diterima, yaitu terdiri atas: H14: 
Penerapan Prinsip Fairness (Kewajaran) berpengaruh signifikan terhadap Kepuasan Pelayanan; H15: Penerapan Prinsip Fairness (Kewajaran) berpengaruh signifikan terhadap Penerimaan Iuran; Fairness (Kewajaran) adalah adalah keadilan dan kesetaraan dalam memenuhi hak-hak setiap pihak yang timbul berdasarkan perjanjian dan perundangundangan yang berlaku terutama yang terkait dengan Kantor Cabang BPJS Ketenagakerjaan di wilayah DKI Jakarta. Hal tersebut di atas menunjukan bahwa upaya Manajemen BPJS Ketenagakerjaan di wilayah DKI Jakarta dalam menerapkan prinsip Fairness (Kewajaran) untuk mendukung operasional dan kinerja Kantor Cabang sudah cukup berdampak langsung dan cukup signifikan kepada Kinerja Kantor Cabang. Kemudian dari variabel yang diukur pada Tabel 6. Regression Weight terdapat lima parameter variabel Fairness (Kewajaran) yang diukur diketahui bahwa seluruhnya memiliki pengaruh terhadap variabel Fairness (Kewajaran) yang dilihat dari Probabilitas (P) dengan nilai default $0,001(* * *)$ atau $<0,05$. Hal ini menunjukan bahwa upaya Manajemen Kantor Cabang BPJS Ketenagakerjaan di wilayah DKI Jakarta dalam menerapkan prinsip Fairness (Kewajaran) untuk mendukung operasional dan kinerja Kantor Cabang sudah terlihat pengaruhnya yang signifikan kepada Kinerja Kantor Cabang, melalui nilai kelima parameter tersebut di atas dan probabilitas $(\mathrm{P})$ kelima paremeternya $<0,05$.

\section{KESIMPULAN DAN SARAN}

Kesimpulan

Dari 5 (lima) prinsip Good Corporate Governance (GCG), terdapat 2 (dua) prinsip GCG Responsibility (Pertanggungjawaban) dan Fairness (Kewajaran) memiliki pengaruh signifikan pada terhadap 3 (tiga) indikator Kinerja Kantor Cabang BPJS Ketenagakerjaan, dengan urutan signifikasinya sebagai berikut:
Penerapan Prinsip Responsibility (Pertanggungjawaban) berpengaruh positif dan signifikan terhadap ketiga indikator kinerja (Peningkatan Kepesertaan, Kepuasan Pelayanan dan Penerimaan Iuran/Efektifitas dan Efisiensi Keuangan). Di samping itu Responsibility (Pertanggungjawaban) memiliki pengaruh yang paling tinggi dibandingkan prinsip GCG lainnya. Hal ini menunjukan bahwa ketiga kinerja utama di Kantor Cabang di wilayah DKI Jakarta sangat dipengaruhi oleh kesesuaian pengelolaan BPJS Ketenagakerjaan terhadap peraturan dan perundang-undangan yang berlaku.

Penerapan Prinsip Fairness (Kewajaran) berpengaruh negatif dan signifikan terhadap ketiga indikator kinerja (Peningkatan Kepesertaan, Kepuasan Peserta dan Penerimaan Iuran). Hal ini menunjukan bahwa ketiga kinerja utama di Kantor Cabang sangat dipengaruhi oleh keadilan dan kesetaraan dalam memenuhi hak-hak para pemangku kepentingan.

Sedangkan Prinsip Independency (Kemandirian), Transparency (Keterbukaan) dan Accountability (Akuntabilitas) tidak berpengaruh signifikan terhadap ketiga indikator kinerja (Peningkatan Kepesertaan, Kepuasan Pelayanan dan Penerimaan Iuran/Efektifitas dan Efisiensi Keuangan).

Terdapat hubungan antara Kelima Prinsip GCG tersebut (Transparansi, Akuntabilitas, Responsibilitas, Independensi dan Fairness), dengan rata-rata hubungan yang tertinggi adalah prinsip Responsibility (Pertanggungjawaban), terutama hubungannya dengan prinsip Akuntabilitas dan Fairness (Kewajaran).

Pencapaian Kinerja Kantor Cabang BPJS Ketenagakerjaan di wilayah DKI Jakarta sangat dipengaruhi oleh prinsip Responsibility (Pertanggungjawaban) dalam penerapan Prinsip Good Corporate Governance (GCG), dibandingkan penerapan prinsip GCG lainnya. Hal ini 
menunjukan bahwa penerapan Good Governance yang merupakan gabungan dari lima prinsip tersebut memiliki pengaruh yang berbeda signifikan dalam pencapaian kinerja Kantor Cabang di wilayah DKI Jakarta.

\section{Saran}

Dalam upaya meningkatkan kinerja Kantor Cabang BPJS Ketenagakerjaan di wilayah DKI Jakarta, manajemen BPJS Ketenagakerjaan wilayah DKI Jakarta agar mengoptimalkan penerapan prinsip-prinsip Good Governance dalam setiap aspek operasional di Kantor Cabang, terutama yang terkait dengan meningkatkan peran dari 3 (tiga) prinsip GCG yang memiliki belum memiliki pengaruh signifikan yaitu Akuntabilitas, Transparansi, dan Independensi. Disamping itu juga perlu dilakukan perbaikan kebijakan atas penerapan prinsip Fairness (Kewajaran) dalam operasional dan pencapaian kinerja Kacab. Hal ini mengingat Kantor Cabang adalah unit kerja terdepan yang berhadapan dengan peserta dan masyarakat (stakeholders) sehingga mendukung pencapaian visi BPJS Ketenagakerjaan.

Kegiatan sosialisasi, evaluasi dan edukasi mengenai implementasi Good Corporate Governance (GCG) tetap harus secara berkala diterapkan oleh BPJS Ketenagakerjaan, di samping itu juga perlu diperbanyak penelitian untuk melakukan perbaikan atas kebijakan GG yang telah diterapkan sehingga kinerja BPJS Ketenagakerjaan wilayah DKI Jakarta semakin baik.

Variabel uji GCG lainnya yang dapat menjaadi pertimbangan untuk ditambah dalam melakukan penelitian yaitu Prediktabilitas (Predictability), Partisipasi (Participation) dan Dinamis (Dynamism) untuk memberikan tingkat keakuratan penilaian kualitas kinerja BPJS Ketenagakerjaan, disamping itu juga variabel laten lainnya yang berpotensi menjadi perantara dari prinsip-prinsip Good Corporate Governance dengan pencapaian Kinerja.

\section{DAFTAR PUSTAKA}

Algaoud, M. Latifa dan K. Marvyn Lewis. Perbankan Syariah Prinsip, Praktik, dan Prospek. alih bahasa Burhan Wirasubrarta, Jakarta: Serambi, 2005.

Cooper, Donald R., \& William Emory. Business Research Methods. Richard D. Irwin, Inc., 1995.

Gibson, John H. Performance versus Results (A Critique of Values in Contemporary Sport). State University of New York, 1993.

Haryono, Siswoyo \& P Wardoyo. Structural equation modeling untuk penelitian manajemen menggunakan AMOS 18. Badan Penerbit PT. Intermedia Personalia Utama, Bekasi, Jawa Barat, 2012.

JR Sitinjak, Tumpal \& Sugiarto. Lisrel. Graha Ilmu Yogyakarta, 2006.

Kaplan, Robert S., \& David P. Norton. The Balanced Scorecard: Measures that Drive Performance. Harvard Business School Publishing, 1992

Lamsah, L. (2018). Pengaruh Motivasi Dan Kepuasan Kerja Terhadap Kinerja Ukm. At-Tadbir: jurnal ilmiah manajemen, 2(2).

Lusiana, H. (2018). Analisis Kinerja Karyawan Terhadap Produktifitas Kerja. At-Tadbir: jurnal ilmiah manajemen, 2(1).

Raykov, T., \& Marcoulides, G.A., A First Course in Structural Equation Modeling (Second Edition), 2006.

Santoso, Singgih. Struktural Equation Modeling (SEM) Konsep dan Aplikasi dengan AMOS 18. PT. Elex Media Komputindo, Jakarta, 2011.

Sugiyono. Metode Penelitian Kuantitatif, Kualitatif, dan R\&D. Bandung: Alfabeta, 2017.

Sutedi, Adrian. Good Corporate Governance. Jakarta : Sinar Grafika, 2011

Thoyibatun, S. (2018). Faktor-faktor yang berpengaruh terhadap perilaku tidak etis dan kecenderungan kecurangan akuntansi 
serta akibatnya terhadap kinerja organisasi. EKUITAS (Jurnal Ekonomi dan Keuangan), 16(2), 245-260.

Yagustana, I Made Gede. Pengaruh Implementasi Good Governance Terhadap Kinerja BPJS Ketenagakerjaan. Tesis. Jakarta : Program Pascasarjana, Universitas Gunadarma, 2016.
Undang-Undang No 24 Tahun 2011 tentang Badan Penyelenggara Jaminan Sosial 